\title{
September on Jessore Road: A Museum of Sufferings
}

\author{
Md. Mohiul Islam
}

\begin{abstract}
Bangladesh emerged as an independent country in the world map in 1971 after a ghastly genocide inflicted by Pakistan (the then West Pakistan). The long nine months lasting war offered the world a sacrifice of 3 millions of people- one of the world's biggest and cruelest genocides in the history of the world. Allen Ginsberg's poem September on Jessore Road is an excellent depiction of the days of those long nine months, it can be considered as a touchy and emotional museum of images of those days' sufferings and pains; in parallel, Ginsberg criticizes his own country, America for not being helpful towards the war victims of Bangladesh. Hence, this paper tries to pay respect to Allen Ginsberg's excellence in depicting the condition of Bangladesh in 1971 through his uses of imageries and through those imageries it also carries the mockery towards America which in fact is a satire towards the whole mankind. Ginsberg raised some questions regarding the role of America during 1971 which actually unmasked the so called aiding organizations along with their owner countries. This paper attempts to put lights on those issues to show the roles of America and some aiding organizations during the liberation war of Bangladesh in 1971.
\end{abstract}

Key Words: Liberation War, Bangladesh, Suffering, Satire, America

\section{Introduction}

\author{
"Millions of babies watching the skies \\ Bellies swollen, with big round eyes \\ On Jessore road- - long bamboo huts \\ No space to shit but sand channel ruts." (Ginsberg 1-4)
}

This is the very beginning stanza of Ginsberg's September on Jessore Road that keeps the readers to hold their breath for few seconds because of the bloody description of the war victims of 71's liberation war of Bangladesh against Pakistan. These feelings and emotions are asserted through some very straight forward utterances and with imageries. Allen Ginsberg portrays the sufferings of the war victim families along with their relatives. In September on Jessore Road, Ginsberg gives a picture of utter despair and destitution. He writes of individuals of all ages with nothing but pain, mud, death and sadness (Stephenson 55). Gradually, he shows the sufferings of the baby, then its father, its mother, its brother, its sister, the aunts, the uncles and finally its grandfather and grandmother. Actually no one was left in 1971 without sufferings in Bangladesh during its liberation war. Allen Ginsberg not only describes the condition of the war victims but also raises some questions towards the government of his country, United States of America. Just as he had with Howl, Ginsberg found that he takes a much grimmer view of his country (Stephenson 55). He raises some questions regarding the activities of the International Non Government Organization, US Aid during the Liberation war of Bangladesh in 1971, as this INGO actually helps the victims of the disasters. Ginsberg throws out some questions towards the government of USA, the military of USA, the Marine troops of USA, US Aid. And through the questions the author actually satirizes the overall system of the government of USA and its different aid organizations which are known for their performances in helping the disaster affected people. Moreover, Allen Ginsberg also raises some questions towards the life style of the American people who are always busy in having the 'American Dreams' and also turning those dreams into truth. As a whole, this poem is a museum of the images of the sufferings of the war affected people and also a satire towards the whole mankind where at the same time the people of one country are fighting for their identity, their liberty, their independence, losing so many lives; in another country people are watching those victims in TV channels with beer cans, having delicious food, leading luxurious life and driving expensive cars.

\section{Literature Review:}

T. S. Eliot in his The Waste Land considers April as the cruelest month of the year due to the contemporary and post Second World War condition of the war affected countries, because the after effects were nothing but the screams and sufferings of the people of the war affected countries. In case of Allen Ginsberg, it is not April; rather it is September in the year of 1971 is month full of sufferings and pains of 
innocent people in Bangladesh. Allen Ginsberg displays the conditions of the war affected people in Bangladesh and also the role of United States of American along with that of some aiding organizations. And this display is done in the tone of mockery and satire.

It seems that the issue of satire on America as well as on the whole human beings in Allen Ginsberg's September on Jessore Road has been discussed less. Not so many remarkable works are found on this very poem, especially Ginsberg's tone of mockery towards America. There are only a few online criticisms on this poem, but those do not focus on the satiric elements though many online articles and published books on America's role in the liberation war of Bangladesh in 1971 are available. Katie M. Stephenson in his essay, "“A Rival of Poetry as Song" Allen Ginsberg, Rock-and-Roll, and the Return to the Bardic Tradition' states Allen Ginsberg's position regarding America's policy towards Bangladesh during its liberation war in 1971.

The Daily Star, a daily newspaper in Bangladesh published an article namely, September on Jessore Road which had discussed very shortly the issue of satire done by Allen Ginsberg.

\section{September in 1971: An Archive of the Images of Sufferings:}

What the people all over the world generally recognize about the history of world civilization is the births of the nations; about the incidents, about the wars which gave the birth of the nations. And when it is about 1971, there is no way to overlook the incident of the Liberation war of Bangladesh against Pakistan. That war lasted for long nine months, took the lives of 3 millions of people of Bangladesh and brought unlimited and intolerable miseries and sufferings for the people of Bangladesh though finally the Bangladeshis got their liberty, got their independence after having a huge sacrifice of the lives of 3 millions of people.

The readers actually do not need to remember the history of the Liberation war of Bangladesh against the contemporary Pakistani government. And Allen Ginsberg also does not talk about the political difficulties and other sensitive issues those were actually present between East Pakistan (Bangladesh at present) and West Pakistan (Pakistan at present) in 1971. Ginsberg in his poem September on Jessore Road, actually draws the image of the conditions of the people of Bangladesh at that time. He talks about how the people of Bangladesh suffered in the war of 1971, how they passed every single day, how they got food, how they ate, where they slept, how they suffered and finally how they died.

One question may be raised that, what is the necessity to study a poem on the Liberation war of Bangladesh in 1971 by an American author, where as there are so many poems, music, dramas, films, novels, short stories and other fictions and non-fictions on this particular issue by so many native authors and writers. But Allen Ginsberg's September on Jessore Road carries a huge importance regarding the condition of the people of Bangladesh during her Liberation War in 1971 against Pakistan. Though many native authors and writers have done so many works on the glorious Liberation war of Bangladesh, but it is worth to study how people and intellectuals from other countries of the world observed the conditions and sufferings of the war affected people of Bangladesh. Ginsberg's September on Jessore Road, in that sense is a very touchy depiction of the discussed issue.

Allen Ginsberg's September on Jessore Road is just a depiction of the sufferings of the war victims in Bangladesh during 1971, but Ginsberg actually talks about only one city of Bangladesh namely Jessore, and this single city works as a representative to bring out the miseries of the war affected people of Bangladesh. And Ginsberg is wise enough to pick Jessore, because Jessore road is the way to go India from Bangladesh and during the Liberation war in 1971 there were so many refugees from Bangladesh who used the Jessore road to flee from their homeland to India for the sake of their lives. So, picking a place and path used by the war victims and the refugees is definitely a wise choice to pen the actual condition of the war affected Bangladesh.

Discussing Ginsberg's September on Jessore Road through the lines and especially in limited words is never an easy tusk to do. Because almost every single line of this poem carries different scenarios of the sufferings of the refugees and the war victims in Bangladesh in 1971. The poem starts depicting the miserable condition of the war victims from its very first stanza. During the war the little babies were watching the skies. Perhaps they were looking for the God for their help, they became thin without having food for a long time and their bellies were swollen with their big round eyes full of hope. Then the description turns towards the fathers who were millions in number and who were really in pain along with the mothers. The fathers, the mothers, the brothers and the sisters, all of them were homeless; they had actually "nowhere to go" (Ginsberg 8). The families were in woe, losing their homes they faced unbound pain with "nowhere to go" (Ginsberg8).

After discussing the conditions and sufferings of the fathers, mothers, brothers and sisters; Ginsberg moves towards the aunts and the uncles; then towards their ancestors, the grandfathers and the grandmothers. All of them became homeless and their unbound sufferings made them mad, made them speechless. Ultimately, the families became homeless by losing their homes along with their sons and daughters. Ginsberg in his $4^{\text {th }}$ stanza says, "Millions of families helpless alone" (Ginsberg 16). Millions of people became homeless and helpless and they did not have any place for their shelter in 1971. They were "homeless on Jessore road under 
the grey sun" (Ginsberg18). They used the Jessore toward Calcutta to leave East Pakistan (Bangladesh at present).

Allen Ginsberg himself witnessed the miserable conditions of the lives of the war victims in Bangladesh during the Liberation war in 1971. He saw the father holding the empty pots for foods with their strength less hands, he saw the mother crying "Maya cry" (Ginsberg36), he saw them living with a very small amount of food. Ginsberg saw how the little children were suffered by the disasters brought by the war in 1971 . He saw the children were silent, they were foodless. In the $10^{\text {th }}$ stanza of the poem, Ginsberg says, "Two children together in palmroof shade/ Stare at me no word is said" (Ginsberg 37-38). May be the children were too weak to talk as they had a very small amount of food because "Rice ration, lentils one time a week" (Ginsberg 39); may be the children were afraid of the stranger, Allen Ginsberg, as they had seen their dear ones got killed by the strangers, Pakistani army.

Ginsberg saw the working people in Bangladesh during the Liberation war in 1971, had lost everything they had. They lose their lands, they lose their money and they lose their every single opportunity of working through which they could make some recoveries during and post-war condition in 1971. There was "No vegetable money or work for the man" (Ginsberg 41). As the men did not have any work to do and any earnings, they could not buy any food or medicines for themselves and their families. And the foods form the reliefs were too small for them and for their families; as a result the scarcity of money food made their lives more miserable. They preserved their foods for the future; they ate less but slowly so that they could eat for a long time. And this actually brought more physical difficulties for them. Ginsberg found that the scarcity of food turned their present food to the food of their future as they reserved more then they ate. Ginsberg found them starving for a long time. On side, they had "No vegetable money", on the other side "The children starves three days in a row/ and vomit their next food unless they eat slow" (Ginsberg 43-44).

Ginsberg saw people facing intolerable situations. He says, "On Jessore road Mother wept at my knees/ Bengali tongue cried mister please" (Ginsberg45-46). The mother wanted a very little help from the author, it might be a begging for food, it might be a begging for shelter, it might be an urge for clothes and money or it might be a begging for their lives. Ginsberg saw not only the mother, he also saw the "Husband still waits at the camp office door" (Ginsberg 48). Perhaps the husband was waiting at the camp office door for his beloved wife who was abducted by the Pakistani army and getting tortured, or who was getting raped by them.

In the next few stanzas in September on Jessore Road Allen Ginsberg describes how he found the relief camps with insufficient foods for the war victims who were very large in number. He describes how people were eagerly waiting for the foods, how they were getting foods form different aid organizations, how the little children were waiting in a maintained line for the food. But Ginsberg was wondering why someone would even smile though s/he does not get what s/he wants/needs.

\section{A Satire on the Entire America:}

Allen Ginsberg hoped to reach a wide American audience with the poem and to expose the hypocrisy of a country that would fund a war in Vietnam but leave countless individuals in the world to die of lack of basic necessities (Stephenson 55). This chapter of the paper will take an approach to investigate another burning issue of Allen Ginsberg's September on Jessore Road, a satire on the entire America as well as the whole mankind. By raising some questions towards the American government, American military, American culture and their responsibilities during the Liberation War, Allen Ginsberg does mock the entire America. He also raises questions towards US Aid and their responsibilities to the war victims. His mockery gets in a strong position when Ginsberg describes the life style of American people in parallel to that of the people of Bangladesh during the Liberation war in 1971 and satirizes them all as human beings. This part of the paper will discuss how Allen Ginsberg satirizes his own nation by keeping all of us under the same umbrella as one nation, which is human nation.

In September on Jessore Road, Allen Ginsberg's use of figurative language reflects his sarcasm and mockery and gives the poem a new dimension with a satiric tone. The metaphor "starving black angels"( Ginsberg 28) in the $7^{\text {th }}$ stanza and the simile "thin legged like elderly nuns" (Ginsberg 30) in the $8^{\text {th }}$ stanza use sarcasm to describe the starving children lining in the road to Calcutta. His sarcasm continues as he describes the ravenous children celebrating the fact that there would be no more rations for them for that week, and as he depicts the illness engulfing the villages.

Ginsberg's mockery reaches the American culture, conformity and war tactics. And Ginsberg uses the mocking tone towards all of these to strengthen his tone of satire and follow his common theme of disliking America and American government due to egoistical actions and unnecessary violence. In different lines in September on Jessore Road Ginsberg uses the tone of mockery. He starts mocking his own country and his government and its war policy. He calls the American war tools as "angels" (Ginsberg 86). When people of Bangladesh were starving during 1971, no American help came here with foods though the people in Bangladesh were in great expectations of it. May be the trucks with foods were stuck in flood, that is why he 
describes the situation of the American vehicles of relief with a tone of sarcasm, "Border trucks flooded, food cant get past/ American machine please come fast."(Ginsberg 85-86). When America has been producing and launching very fast cars and strong muscle cars, at that very moment their vehicles with foods and other staffs are seemed to be stuck in the flood and the muddy land! They were late! This is really unbelievable. Because Ginsberg did not find any relief vehicles came to Bangladesh during the Liberation war in 1971. Like Allen Ginsberg, many people expected help from the American government and American aircrafts as "Angel Machines" which would come down from the sky with foods and medicines; but those did not came. Rather those might be busy with their mission of invading other countries by killing innocent people. The angels were busy in devilish deeds.

Question has been raised by Allen Ginsberg regarding the role of the government of America, against the bunkers of American soldier for the shelter and safety of them as the American government are failed to give any shelter to the war affected people and the refugees to save their lives, to save them from the bombs of the Pakistani army. Ginsberg asks question about the role of the American army's helicopter which may be busy with bombing on some other countries, which may be busy with the newly invented machineguns, killing the playful little children like a game. He mocks, 'Where is Ambassador Bunker today? /Are this Helios machingunning children at play?' (Ginsberg87-88)

Ginsberg's mockery continues in the next few lines of the poem, and this time it is about the role of US Aid which has its fame as one of the renowned international helping organization in all over the world; and also the role of the American Air force. Ginsberg raises questions about the role US Aid during the Liberation war in Bangladesh in 1971. When he was in Bangladesh he found no helicopter from US Aid came with any sort of aid and relief for the refugees and the war affected people. To Ginsberg, it seemed that those helicopters were busy with selling drugs in Bangkok. It is not only the US Aid, Ginsberg also raises question against the role of the Air force of America. He did not find any sign of help form US Air force for the war affected people in Bangladesh. No airplanes came from US Air force to help Bangladesh at that time; they were always busy with not helping anyone rather with invading North Laos and killing people in 1971. Ginsberg asks,

\author{
"Where are the helicopters of US Aid? \\ Smuggling dope in Bangkok's shade. \\ Where is America's Air force of Light? \\ Bombing North Laos all day and all night?" (Ginsberg89-92)
}

Allen Ginsberg does not stop himself just after questioning the role of US Aid and the air force of America; he uses his tone of mockery towards the role of American "armies of Gold" (Ginsberg 93) and "Billionaire Navies" (Ginsberg 94). America has been being considered as one of the strongest countries with the strongest military defense in the world. But unfortunately, Ginsberg saw no sign of help with neither medicine nor food for the war victims from US army though the army was considered as "armies of Gold" by the government. Same thing happened with the Billionaire Navy of America. They did not come too. The US government invested huge amount of money to create a strong navy with expensive heavyweight war weapons. Allen Ginsberg, seeing no help from the American defense, asks the US government that were the "armies of Gold" and "Billionaire Navies" doing any relief work or they were invading and bombing on other countries like North Viet Nam as they had done so in past, and causing more grieves and sufferings for the innocent people instead of relief. A tone of mockery and satire is completely visible in Allen Ginsberg's voice,

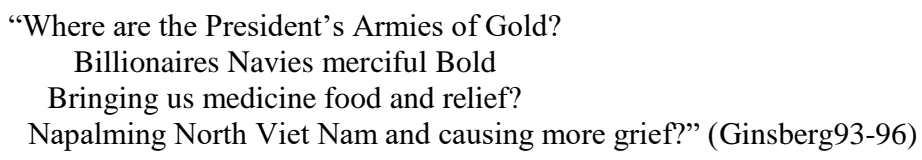

Allen Ginsberg not only criticizes the US government and the military of America, he also criticizes the civil people of America. He criticizes the life style of the people of America. While millions of people are being killed in Bangladesh, while millions of fathers are losing their sons and daughters, while millions of babies losing their parents, while millions of aunts and uncles are dyeing with holes in their heads, while millions of grandfathers and grandmothers are dying and becoming ghosts; at that very moment people in America are watching TV, thinking about cities and cars; while millions of children are starving and passing day after day without any piece of food; at the same time people in America are enjoying their suppers and dinners with delicious foods by sitting inside a room in New York city. Ginsberg finds no reason or no logic working behind this kind of life of the American people but just inhumanity. He asks,

"What should we care for our cities and cars?

What shall we buy with our Food stamps on Mars?

How many millions sit down in New York

\& Sup this night's table on bone \& roast pork?" (Ginsberg121-124)

Criticism on the 'American Dreams' is also found in the voice Allen Ginsberg as he continues to pen the worthless behavior and lifestyle of the American people while millions of people are being killed, while millions of babies are starving 
and becoming homeless. Most of the people in America are busy in having the 'American Dreams' and they believe in those dreams; they are running after the absurd dreams. They always think of having fast cars, having own home and land. They burn cigars and gasoline for the fast lavish cars and they are actually contributing in the air pollution. They are spending a lot of money in buying beer cans and alcohols, but not in helping other poor people. They are throwing away the alcohols into the rivers and seas and thus killing the mother earth by polluting her environment. They are destroying the resources for the entire human being and dreaming worthless matters instead of helping the refugees and war affected people in Bangladesh. Ginsberg throws some questions towards the dreaming people in America,

\author{
"How many millions of beer cans are tossed \\ in Oceans of Mother? How much does She cost? \\ Cigars gasolines and asphalt car dream \\ Stinking the world and dimming star beams- -" (Ginsberg 125-128)
}

Actually, Allen Ginsberg criticizes the intellects of the American government as well as that of the common people in America. Because it is not only the responsibility of the government to help the refugees, but the common people too have some duties and responsibilities to the refugees and the war affected people in other countries. And from this point of view, Allen Ginsberg raises a serious question which actually discloses the mentality of the Americans. He asks the Americans to use even the electric shock so that their "America Brain" (Ginsberg 108) works for the betterment of the war affected people in Bangladesh as well as for the betterment of the rest of the world, "Ring out ye bells of electrical pain/ Ring in the conscious of America brain" (Ginsberg 107-108). But Ginsberg's tone of mockery reaches the completeness when he criticizes the role of people in all over the world, when he urges to us to see and feel everything from one nation's eye, which is human nation. He urges us to feel every second of the refugees of Bangladesh, he urges us to be human, which is a direct attack on the inhuman nature of the whole human kind with a tone of serious mockery, "Finish the war in your breast with sigh/ Come tast the tears in your own Human eye" (Ginsberg129-130).

\title{
V. Conclusion:
}

Though, Allen Ginsberg composed his poem September on Jessore Road almost forty three years ago, still this poem carries the same significance and essence regarding different affected countries at present time like Iraq, Afghanistan and Syria etc. Because everywhere same scenarios are found; and everywhere America is causing all damages and problems by invading those countries in the name of establishing democracy in those countries. In fact, America is neither establishing democracy nor they are helping the poor people in different countries; rather America is causing more blood shades to stop the blood shades in the mother earth. And Ginsberg has just brought the history of Bangladesh as a representative of the war affected countries in the world. So, the poem, September on Jessore Road does carry the universal appeal of the ironic role of America to establish peace in the world through a tone of serious mockery with the description of the miseries and sufferings of the refugees and the war affected people during the Liberation war of Bangladesh in 1971.

In the concluding remarks, there are stills a few issues to be discussed regarding this poem which give a very clear idea of the inhumanity of the human beings. In September on Jessore Road, Ginsberg shows each and every member of the family is facing dangers and dying miserable death, no one is spared from the animalistic inhuman hands of the humans. He brings Bangladesh as a representative of all the war affected countries. And unfortunately, after all these mockeries and satires, the situation remains the same. The starting and the ending of the poem are almost sharing the same meanings,

\author{
"Millions of babies in pain \\ Millions of mothers in rain \\ Millions of brothers in woe \\ Millions of children nowhere to go.” (Ginsberg149-152)
}

\section{References}

[1]. Eliot, T.S. The Waste Land. Poetry Foundation. Poetry Foundation, n.d. Web. 9 March 2014.

[2]. Ginsberg, Allen. September on Jessore Road, Poetry Foundation. Poetry Foundation, n.d. Web. 9 March 2014.

[3]. http://annmariacoughlan.wordpress.com/tag/september-on-jessore-road/ 9 March 2014

[4]. http://archive.thedailystar.net/newDesign/news-details.php?nid=153299 9 March 2014

[5]. http://indrus.in/articles/2011/12/20/1971_war_how_russia_sank_nixons_gunboat_diplomacy_14041.html 9 March 2014

[6]. http://www.eliteskills.com/c/10582 9 March 2014

[7]. http://www.hindustantimes.com/world-news/us-role-in-1971-b-desh-war-tragic-mistake-envoy/article1-449768.aspx 9 March 2014

[8]. http://www.rediff.com/news/2006/dec/26claude.htm 9 March 2014

[9]. http://zeenews.india.com/news/south-asia/us-role-in-1971-b-desh-independence-war-tragic-mistake_560471.html 9 March 2014

[10]. Stephenson, Kaite M. "'A Revival of Poetry as Song" Allen Ginsberg, Rock-and-Roll, and the Return to the Bardic Tradition' https://www.google.com/url?sa=t\&rct=j\&q=\&esrc=s\&source=web\&cd=3\&cad=rja\&uact=8\&ved=0ahUKEwj5nZiDya3KAhUUSo 4KHSXmBNEQFggrMAI\&url=http $\% 3 \mathrm{~A} \% 2 \mathrm{~F} \% 2 \mathrm{Fwww}$.und.edu $\% 2$ Forg $\% 2$ Fjfkconference $\% 2$ FJFKChapter6R.doc\&usg=AFQjCN Hb1aPRJiIgtxuiIvOWfjstRsSpjQ January 16, 2016, 11:05:31 AM 